\title{
Determinan Tax Avoidance Perusahaan Manufaktur di Indonesia
}

Hadi Sutomo ${ }^{1}$, Syahril Djaddang ${ }^{2}$

${ }^{1.2}$ Universitas Pancasila, Jl. Srengseng Sawah, Jagakarsa, Jakarta Selatan, 12640

INFO ARTIKEL

JEL Classsification: H26

G31

Keywords:

effectice tax rate, profitability, leverage, capital intensity, inventory intensity, liquidity.

\begin{abstract}
A B S T R A C T
This study was conducted with the aim to analyze the effect of profitability, leverage, capital intensity, inventory intensity, and liquidity to tax avoidance. Samples of research are 330 data of manufacturing companies listed on Indonesia Stock Exchange 2011-2015. The results showed that profitability, capital intensity and inventory intensity are the determinants of tax avoidance while leverage and liquidity have no significant effect on tax avoidance. Nevertheless, the result of this research is still not optimal due to the limited of research object and the number of independent variables used and the ETR variable is still not accurate if used as a proxy to measure tax avoidance. Therefore for future research is suggested to expand the sample and increase the number of independent variables and use CTTOR variable as a proxy to measure tax avoidance so that the expected results of research becomes more optimal.
\end{abstract}

\begin{abstract}
A B S T R A K
Penelitian ini dilakukan dengan tujuan untuk menganalisis pengaruh profitabilitas, leverage, capital intensity, inventory intensity, dan likuiditas terhadap tax avoidance. Sampel penelitian sebanyak 330 data perusahaan manufaktur yang terdaftar di Bursa Efek Indonesia tahun 2011-2015. Hasil penelitian menunjukan bahwa profitabilitas, capital intensity dan inventory intensity merupakan determinan tax avoidance sedangkan leverage dan likuiditas tidak berpengaruh signifikan terhadap tax avoidance. Namun demikian hasil penelitian ini masih belum optimal dikarenakan terbatasnya objek penelitian dan jumlah variable independen yang digunakan serta variable ETR dinilai masih belum tepat apabila digunakan sebagai proksi untuk mengukur tax avoidance. Oleh karena itu untuk penelitian yang akan datang disarankan untuk memperluas sampel dan menambah jumlah variable independen serta menggunakan variable CTTOR sebagai proksi untuk mengukur tax avoidance sehingga diharapkan hasil penelitian menjadi lebih optimal.
\end{abstract}

*Email Korespondensi: 'hadi_sutomo@yahoo.com,2djaddangsyahril@gmail.com 


\section{Pendahuluan}

Pajak merupakan sumber penerimaan negara yang sangat penting, sebab pajak sangat diperlukan untuk membiayai penyelenggaraan pemerintahan dan pembangunan nasional disegala bidang secara berkelanjutan. Beban penyelenggaraan pemerintahan dan pembangunan nasional setiap tahunnya terus mengalami peningkatan sehingga pemerintah melalui Direktorat Jenderal Pajak selalu berupaya untuk meningkatkan target penerimaan pajak setiap tahunnya meskipun upaya tersebut masih sulit untuk direalisasikan. Hal ini dapat tercermin dari menurunnya prosentase realisasi penerimaan pajak negara terhadap anggaran penerimaan pajak negara dalam kurun waktu tahun 2011-2015 yaitu dari 99,44\% pada tahun 2011 menjadi $96,48 \%$ pada tahun 2012 , dari 96,48\% pada tahun 2012 menjadi 93,81\% pada tahun 2013 , dari $93,81 \%$ pada tahun 2013 menjadi 92,04\% pada tahun 2014 dan dari 92,04\% pada tahun 2014 menjadi 83,29\% pada tahun 2015. Sebuah surat kabar elektronik finansial.bisinis.com menginformasikan bahwa perusahaan sektor manufaktur telah menjadi penyebab menurunnya penerimaan pajak penghasilan $(\mathrm{PPh})$ non migas pada tahun 2012 sebesar 1,75\% dibandingkan dengan tahun 2011.

Kondisi tersebut diatas diduga sebagai akibat dari adanya tindakan penghindaran pajak (tax avoidance) yang dilakukan oleh pihak korporasi atau perusahaan, sebab selama ini terdapat perbedaan pandangan antar perusahaan dengan pemerintah, dimana perusahaan berpandangan bahwa pajak adalah bagian dari biaya pelaksanaan usaha (cost of doing bussines) yang dapat mengurangi laba sehingga perusahaan akan berupaya melakukan penghindaran pajak (tax avoidance) guna memaksimalkan laba dan meminimalkan pajak, sedangkan pemerintah berpandangan bahwa pajak adalah kewajiban yang harus dibayar oleh setiap wajib pajak demi memaksimalkan penerimaan negara. Peghindaran pajak (tax avoidance) pajak berkenaan dengan pengaturan sesuatu peristiwa sedemikian rupa untuk meminimalkan atau menghilangkan beban pajak dengan memperhatikan ada atau tidaknya akibat-akibat pajak yang ditimbulkannya. Oleh karena itu, penghindaran pajak tidak merupakan pelanggaran atas undang-undang pajak atau secara etika dianggap salah dalam usaha wajib pajak untuk mengurangi, menghindari, meminimalkan, atau meringankan beban pajak dengan cara-cara yang dimungkinkan oleh undang-undang pajak (Santoso dan Rahayu, 2013:4).

Beberapa penelitian terdahulu telah menggunakan Effective Tax Rate (ETR) sebagai proksi untuk mengukur penghindaran pajak (tax avoidance) diantaranya yang dilakukan oleh Ratmono dan Sagala (2015) dan Siregar \& Widyawati (2016). ETR menunjukkan besarnya porsi beban pajak terhadap laba sebelum pajak, semakin tinggi nilai ETR maka akan mencerminkan tingkat penghindaran pajak yang rendah dan sebaliknya. Dari hasil penelitian terdahulu beberapa diantaranya menyatakan bahwa profitabilitas, leverage, capital intensity, inventory intensity dan likuiditas merupakan variable yang dapat mempengaruhi ETR, namun beberapa diantaranya lagi mengatakan bahwa variable tersebut tidak berpengaruh terhadap ETR, sehingga masih terjadi reseach gap.

Hasil penelitian yang dilakukan oleh Pradipta dan Supriyadi (2015), dan Kurniasih dan Sari (2013) menyatakan bahwa profitabiliats berpengaruh negatif signifikan terhadap penghindaran pajak (tax avoidance), namun hasil penelitian tersebut tidak sependapat dengan hasil penelitian yang dilakukan oleh Siregar dan Widyawati (2016), dan Jessica dan Toly (2014) yang menyatakan bahwa profitabilitas tidak berpengaruh signifikan terhadap penghindaran pajak (tax avoidance). Berkaitan dengan leverage, hasil penelitian yang dilakukan oleh Siregar \& Widyawati (2016), Suyanto dan Supramono (2012) mengatakan bahwa leverage berpengaruh positif signifikan terhadap tindakan penghindaran pajak (tax avoidance), 
namun hasil penelitian ini berbeda dengan yang dilakukan oleh Wijayanti et al. (2016), dan Pradipta dan Supriadi (2015) yang mengatakan bahwa leverage tidak perpengaruh signifikan terhadap penghindaran pajak (tax avoidance).

Hasil penelitian yang dilakukan oleh Jessica dan Toly (2014), dan Lanis dan Richardson (2011) menyatakan bahwa capital intensity berpengaruh positif signifikan terhadap penghindaran pajak (tax avoidance). Namun tidak sependapat dengan hasil penelitian yang dilakukan oleh Siregar dan Widyawati (2016) dan Adisamartha dan Noviari (2015) yang menyatakan bahwa capital intensity tidak berpengaruh signifikan terhadap penghindaran pajak (tax avoidance). Kemudian hasil penelitian yang dilakukan oleh Ratmono dan Sagala (2015) dan Surbakti (2012) yang menyatakan bahwa inventory intensity berpengaruh negatif signifikan terhadap penghindaran pajak (tax avoidance), sedangkan hasil penelitian Siregar dan Widyawati (2016) dan Lanis dan Richardson (2011) yang menyatakan bahwa inventory intensity tidak berpengaruh signifikan terhadap penghindaran pajak (tax avoidance). Selanjutnya hasil penelitian yang dilakukan oleh Siahaan (2005) dan Bradley (1994) yang menyatakan bahwa likuiditas berpengaruh negatif terhadap penghindaran pajak (tax avoidance), namun hasil penelitian berbeda dengan yang dilakukan oleh oleh Tiaras dan Wijaya (2015) dan Suyanto dan Supramono (2012) yang menyatakan bahwa likuiditas tidak berpengaruh signifikan terhadap penghindaran pajak (tax avoidance).

Penelitian ini merupakan pengembangan dari penelitian sebelumnya yaitu penelitian Siregar dan Widyawati (2016) yang berjudul Pengaruh Karakteristik Perusahaan Terhadap Penghindaran Pajak Pada Perusahaan Manufaktur Di BEI. Perbedaan penelitian ini dengan penelitian Siregar \& Widyawati (2016) terletak pada sampel, variable dan tahun penelitian, yaitu penelitian ini menggunakan variabel profitabilitas, leverage, capital intensity, inventory intensity dan likuiditas serta menggunakan proksi ETR untuk mengukur penghindaran pajak perusahaan, Sampel perusahaan yang digunakan merupakan perusahaan manufaktur yang terdaftar di BEI tahun 2011-2015. Sedangkan Siregar \& Widyawati (2016) menggunakan variable independen profitabilitas (ROA), size, leverage, capital intensity, inventory intensity serta menggunakan proksi ETR untuk mengukur penghindaran pajak, sampel perusahaan yang digunakan merupakan perusahaan manufaktur yang terdaftar di BEI tahun 2010-2014.

Berdasarkan uraian pada latar belakang, maka tujuan dari penelitian ini adalah untuk menginvestigasi dan mengetahui secara empiris bahwa profitabilitas, leverage, capital intensity, inventory intensity dan likuiditas berpengaruh terhadap tax avoidance.

\section{Telaah Teori dan Pengembangan Hipotesis}

\section{Teory Agensi (Agency Theory)}

Teori keagenan menyatakan bahwa hubungan keagenan sebagai kontrak antara satu atau beberapa orang (principals) yang mempekerjakan orang lain (agent) untuk melakukan sejumlah jasa dan memberikan wewenang dalam pengambilan keputusan. (Jensen dan Meckling, 1976 dalam Kurniasih dan Sari, 2013). Dalam teori keagenan, manajemen perusahaan menyajikan laporan keuangannya berdasarkan: (1) motivasi opportunistic, dimana motivasi tersebut mendorong manajemen untuk melakukan manajemen laba sehingga laba yang disajikan dalam laporan keuangan menjadi lebih tinggi demi mendapatkan insentif, (2) motivasi signaling, dimana manajemen akan menyajikan laporan keuangan yang berkualitas agar menimbulkan sinyal positif terhadap investor dan sebagai evaluasi kinerja manajemen.

Motivasi manajemen dalam menyajikan laporan keuangan tersebut dapat menimbulkan terjadinya asimetri informasi yang dapat menyebabkan masalah keangenan, 
sebab laporan keuangan yang disajikan oleh manajemen (agens) akan memberikan informasi yang tidak mencerminkan kondisi perusahaan yang sebenarnya kepada para pengguna laporan keuangan seperti pemilik, pemegang saham dan stakeholder lainnya. Berdasarkan penjelasan ini maka dapat diasumsikan bahwa tindakan penghindaran pajak perusahaan merupakan tindakan manajemen yang dimotivasi oleh opportunistic dan signaling untuk kepentingan intensif, evaluasi kinerja atau sinyal positif pada investor, meskipun tindakan tersebut dapat berisiko dikenai sanksi perpajakan dan sosial sedangkan para pemilik atau pemegang saham cenderung akan menolak adanya tindakan penghindaran pajak perusahaan demi menjaga reputasi dan nama baik perusahaan.

\section{Penghindaran Pajak (Tax Avoidance)}

Penghindaran pajak (tax avoidance) merupakan suatu cara mengurangi pajak yang masih dalam batas ketentuan peraturan perundang-undangan perpajakan dan dapat dibenarkan, terutama melalui perencanaan pajak (Santoso dan Rahayu, 2013:4). Penghindaran pajak dapat dikategorikan sebagai tindakan yang legal sepanjang dilakukan melalui suatu perencanaan dan tidak melanggar peraturan pajak yang belaku serta dilakukan dengan tujuan untuk menunda atau mengalihkan pembebanan pajak ke periode berikutnya sehingga beban pajak pada periode berjalan tidak memberatkan bahkan sampai mengganggu cash flow perusahaan.

\section{Profitabiltas}

Profitabilitas merupakan rasio untuk menilai kemampuan perusahaan dalam mencari keuntungan atau laba. Rasio ini memberikan ukuran tingkat efektivitas manajemen suatu perusahaan, hal ini ditunjukan oleh laba yang dihasilkan dari penjualan dan pendapatan investasi (Kasmir, 2015 : 196). Profitabilitas merupakan salah satu pengukuran kinerja perusahaan yang menunjukan kemampuan perusahaan dalam memanfaatkan asetnya secara efisien dalam menghasilkan laba perusahaan. Dalam beberapa penelitian sebelumnya profitabilitas diproksikan dengan Return On Assets, dimana nilai ROA yang tinggi menunjukan kinerja perusahaan yang semakin bagus (Pradipta dan Supriyadi: 2015).

\section{Leverage}

Leverage adalah merupakan rasio yang digunakan untuk mengukur sejauh mana aktiva perusahaan dibiayai dengan utang (Kasmir, 2015 : 151). Leverage merupakan rasio yang menunjukan besarnya utang yang dimiliki perusahaan untuk membiayai aktivitas operasinya (Darmawan dan Sukartha, 2014). Leverage sebagai rasio yang timbul apabila dalam kegiatan operasionalnya perusahaan menggunakan dana pinjaman atau menggunakan dana yang memiliki beban bunga (Siswianti dan Kiswanto, 2016).

\section{Capital Intensity}

Capital Intensity merupakan rasio perbandingan total asset tetap bersih terhadap total asset (Lanis dan Richardson, 2011). Intensitas aset tetap adalah seberapa besar proporsi aset tetap perusahaan dalam total aset yang dimilki perusahaan (Siregar dan Widyawati, 2016). Capital intensity menggambarkan seberapa besar aset perusahaan yang diinvestasikan dalam bentuk aktiva tetap (Mulyani et al., 2014).

\section{Inventory Intensity}

Inventory intensity atau intensitas persediaan merupakan perbandingan antara total persediaan terhadap total aset (Lanis dan Richardson, 2011). Menurut menyatakan bahwa inventory intensity atau bisa disebut juga dengan intensitas persediaan merupakan salah satu komponen penyusun aktiva yang diukur dengan membandingkan antara total persediaan dengan total asset yang dimiliki perusahaan (Siregar dan Widyawati, 2016). 


\section{Likuiditas}

Likuditas mengacu pada kemampuan perusahaan untuk memenuhi kewajiban jangka pendeknya. Likuiditas merupakan kemampuan untuk mengubah aktiva menjadi kas atau kemampuan untuk memperoleh kas (Wild, et $a l, 2004$ : 185). Kemampuan perusahaan untuk melaksanakan kewajiban jangka pendeknya dapat dilihat dari rasio likuiditas, apabila perusahaan memiliki rasio likuiditas yang tinggi maka perusahaan tersebut sedang berada dalam kondisi arus kas yang lancar, sehingga kewajiban jangka pendek akan mampu dipenuhi (Adisamartha dan Noviari, 2015).

\section{Perumusan Hipotesis

Pengaruh Pofitabilitas terhadap Tax

Profitabilitas merupakan rasio keuangan yang menunjukan kemampuan sebuah perusahaan dalam memanfaatkan asetnya untuk menghasilkan laba. Semakin tinggi laba maka akan semakin tinggi beban pajak yang harus dibayarkan. Sesuai sudut pandang bisnis bahwa pajak adalah bagian dari biaya pelaksanaan usaha (cost of doing bussines) yang akan mengurangi pendapatan oleh karena itu perusahaan akan berusaha memaksimalkan laba sebelum pajak dan meminimalkan biaya pajak dengan merancang cara melalui perencanaan pajak yang efektif melalui skema penghindaran pajak ( $\operatorname{tax}$ avoidance).

Dari penjelasan tersebut terdapat hubungan antara profitabilitas dengan tax avoidance. Sesuai penelitian terdahulu yang dilakukan oleh Pradipta dan Supriyadi (2015) dan Kurniasih dan Sari (2013) menyatakan bahwa profitabilitas berpengaruh negatif signifikan terhadap penghindaran pajak (tax avoidance). Berdasarkan hal tersebut diatas maka penulis merumuskan hipotesis pertama sebagai berikut :

\section{$\mathrm{H}_{1}$ : Profitabilitas berpengaruh negatif ter-} hadap tax avoidance.

\section{Pengaruh Leverage terhadap Tax Avoidance}

Rasio leverage yang tinggi menunjukan besarnya jumlah pendanaan perusahaan yang bersumber dari utang, sehingga akan menimbulkan jumlah beban bunga yang tinggi. Beban bunga adalah komponen biaya yang dapat mengurangi laba sehingga akan menurunkan beban pajak perusahaan. Dari sudut pandang bisnis bahwa ketika perusahaan berhutang kepada pihak ketiga maka perusahaan juga akan berusaha untuk meningkatkan laba agar dapat membayar pokok hutang dan beban bunga. Namun pada umumnya perusahaan akan lebih mengutamakan untuk membayar beban bunga daripada beban pajak, sehingga hal ini menyebabkan perusahaan berupaya melakukan penghindaran pajak (tax avoidance).

Sesuai hasil penelitian terdahulu diantaranya yang dilakukan oleh Siregar \& Widyawati (2016), dan Mayangsari (2015) mengatakan bahwa leverage berpengaruh positif signifikan terhadap tindakan penghindaran pajak (tax avoidance). Berdasarkan hal tersebut diatas maka penulis merumuskan hipotesis kedua sebagai berikut :

\section{$\mathrm{H}_{2}$ : Leverage berpengaruh positif terhadap tax avoidance}

\section{Pengaruh Capital Intensity terhadap Tax Avoidance}

Capital intensity merupakan salah satu pengukuran kinerja perusahaan yang menggambarkan seberapa besar proporsi aset tetap terhadap total aset yang dimiliki perusahaan. Jumlah aset tetap yang tinggi akan menimbulkan beban depresiasi yang tinggi. Sesuai sudut pandang bisnis, aset tetap digunakan untuk mendukung produktivitas perusahaan dalam menghasilkan laba yang tinggi, akan tetapi perusahaan juga akan memanfaatkan beban depresiasi untuk mengurangi laba guna menurunkan beban pajak. Sehingga terdapat hubungan antara capital intensity terhadap penghindaran pajak (tax avoidance). 
Sesuai hasil penelitian sebelumnya diantaranya yang dilakukan oleh Jessica dan Toly (2014), dan Lanis dan Richardson (2011) yang menyatakan bahwa capital intensity berpengaruh positif signifikan terhadap penghindaran pajak (tax avoidance). Berdasarkan hal tersebut diatas maka penulis merumuskan hipotesis ketiga sebagai berikut :

\section{$\mathrm{H}_{3}$ : Capital intesity berpengaruh positif terhadap tax avoidance}

\section{Pengaruh Inventory Intensity terhadap Tax Avoidance}

Inventory intensity merupakan salah satu ukuran kinerja perusahaan yang menggambarkan seberapa besar proporsi persediaan barang dagangan terhadap total aset yang dimiliki oleh perusahaan. Semakin tinggi nilai persediaan mencerminkan semakin rendahnya nilai harga pokok penjualan sehingga akan menyebabkan laba perusahaan dan beban pajak yang semakin tinggi. Sesuai sudut pandang bisnis bahwa ketika inventory intensity dapat mempengaruhi peningkatan laba dan beban pajak maka perusahaan akan berusaha memaksimalkan laba dan meminimalkan biaya dengan merancang cara melalui perencanaan pajak (tax planning) yang efektif melalui skema penghindaran pajak (tax avoidance).

Sesuai hasil penelitian terdahulu yang dilakukan oleh Ratmono dan Sagala (2015) dan Surbakti (2012) yang menyatakan bahwa inventory intensity berpengaruh negatif signifikan terhadap penghindaran pajak (tax avoidance). Berdasarkan hal tersebut diatas maka penulis merumuskan hipotesis keempat sebagai berikut :

\section{$\mathrm{H}_{4}$ : Inventory intesity berpengaruh negatif terhadap tax avoidance}

\section{Pengaruh Likuiditas terhadap Tax Avoidance}

Perusahaan yang memiliki likuiditas tinggi akan mencerminkan kondisi keuangan yang baik sehingga perusahaan akan memilki kemampuan untuk membayar seluruh kewajibannya termasuk kewajiban membayar pajak, sebaliknya perusahaan yang likuiditasnya rendah maka akan lebih memilih untuk menjaga cash flows daripada harus membayar beban pajak demi mengamankan keuangan perusahaan. Sehingga terdapat hubungan antara likuiditas terhadap penghindaran pajak (tax avoidance). Sesuai hasil penelitian yang dilakukan oleh Siahaan (2005) dan Bradley (1994) yang menyatakan bahwa likuiditas berpengaruh negatif terhadap penghindaran pajak (tax avoidance). Berdasarkan hal tersebut diatas maka penulis merumuskan hipotesis sebagai berikut :

\section{$\mathrm{H}_{5}$ : Likuiditas berpengaruh negatif terhadap} tax avoidance

\section{Metode}

\section{Populasi dan Sampel}

Populasi yang digunakan dalam penelitian ini adalah perusahaan manufaktur dari semua sektor yang terdaftar di Bursa Efek Indonesia periode tahun 2011-2015. Alasan memilih perusahaan manufaktur dari semua sektor tersebut adalah agar penelitian ini relevan dengan fenomena dari penelitian ini. Metode pengambilan sampel adalah purposive sampling yaitu tidak semua populasi dijadikan sampel namun hanya populasi dengan kriteria dan pertimbangan tertentu saja yang dijadikan sampel.

Sampel adalah perusahaan manufaktur dari semua sektor yang terdaftar di Bursa Efek Indonesia(BEI) periode tahun 2011-2015 dengan kriteria laporan keuangan harus menggunakan mata uang Rupiah, harus laba selama dalam periode sampel, melaporkan laporan keuangan dalam periode sampel, dan menyediakan akun terkait variabel yang dibutuhkan selama periode sampel. Dalam penelitian ini jumlah sampel yang diambil sebanyak 330 emiten dari total populasi.

\section{Variable dan Definisi Operasional Variabel}

Variabel dan definisi operasional masingmasing dapat dijelaskan dalam tabel 1 sebagai berikut : 
Tabel 1. Definisi Operasional Variabel

\begin{tabular}{|c|c|c|c|c|}
\hline Variable & Definisi & $\begin{array}{l}\text { Skala } \\
\text { Ukur }\end{array}$ & & Indikator \\
\hline $\begin{array}{c}\text { Tax Avoidance } \\
\text { (Y) }\end{array}$ & $\begin{array}{l}\text { Cara untuk menghidari pajak secara } \\
\text { legal yang tidak melanggar peraturan } \\
\text { perpajakan (Wijayanti, et al., 2016) }\end{array}$ & Rasio & ETR & $\frac{\text { Beban Pajak }}{\text { Laba Sebelum Pajak }}$ \\
\hline $\begin{array}{l}\text { Profitabilitas } \\
\qquad\left(\mathrm{X}_{1}\right)\end{array}$ & $\begin{array}{l}\text { Kemampuan perusahaan untuk } \\
\text { menghasilkan laba yang mencer- } \\
\text { minkan kinerja suatu perusahaan } \\
\text { (Pradipta dan Supriyadi , 2015) }\end{array}$ & Rasio & ROA & $\frac{\text { Laba Sesudah Pajak }}{\text { Total Aset }}$ \\
\hline $\begin{array}{l}\text { Leverage } \\
\qquad\left(\mathrm{X}_{2}\right)\end{array}$ & $\begin{array}{l}\text { Kemampuan perusahaan untuk } \\
\text { membayar seluruh kewajibannya, } \\
\text { baik jangka pendek maupun jangka } \\
\text { panjang apabila perusahaa dibubar- } \\
\text { kan Kasmir (2015:151) }\end{array}$ & Rasio & LEV & $\begin{array}{r}\text { Total Hutang } \\
\text { Total Aset }\end{array}$ \\
\hline $\begin{array}{l}\text { Capital } \\
\text { Intensity } \\
\quad\left(\mathrm{X}_{3}\right)\end{array}$ & $\begin{array}{l}\text { Rasio yang menggambarkan sebera- } \\
\text { pa besar aset perusahaan yang diin- } \\
\text { vestasikan dalam bentuk aktiva tetap } \\
\text { (Mulyani } \text { et al., 2014). }\end{array}$ & Rasio & CAPIN & $\frac{\text { Total Aset Tetap Bersih }}{\text { Total Aset }}$ \\
\hline $\begin{array}{l}\text { Inventory } \\
\text { Intensity } \\
(\mathrm{X})\end{array}$ & $\begin{array}{l}\text { Komponen penyusun aktiva yang } \\
\text { menggambarkan proporsi persediaan } \\
\text { yang dimiliki terhadap total asset }\end{array}$ & Rasio & INVINT $=$ & Total Persediaan \\
\hline & $\begin{array}{l}\text { perusahaan. (Siregar dan Widyawati } \\
\text {,2016) }\end{array}$ & & IIVVIVI- & Total Aset \\
\hline $\begin{array}{l}\text { Likuiditas } \\
\qquad\left(\mathrm{X}_{5}\right)\end{array}$ & $\begin{array}{l}\text { Kemampuan perusahaan untuk } \\
\text { melaksanakan kewajiban jangka } \\
\text { pendeknya dapat dilihat dari rasio } \\
\text { likuiditas (Adisamartha dan Noviari, } \\
\text { 2015). }\end{array}$ & Rasio & $\mathrm{CR}$ & $=\frac{\text { Total Aktia Lancar }}{\text { Total Hutang Lancar }}$ \\
\hline
\end{tabular}

\section{Teknik Analisis}

\section{Analisis Deskriptif}

Analisis deskriptif merupakan bentuk analisis data penelitian untuk menguji generalisasi hasil penelitian dari suatu sampel (Siregar dan Widyawati, 2016). Analisis deskriptif digunakan untuk menilai karakteristik dari sebuah data diantaranya seperti minimum, maximum, mean dan standar deviasi.

\section{Pengujian Uji Asumsi Klasik}

Pengujian asumsi klasik adalah persyaratan statistik yang harus dipenuhi pada analisis linear berganda yang berbasis OLS (ordinary least square), OLS merupakan metode regresi yang meminimalkan jumlah kesalahan (error) kuadrat. Pengujian ini dilakukan agar hasil analisis regresi memenuhi kriteria BLUE (Best Liniear Unbiased Estimator). Pengujian asumsi klasik yang sering digunakan yaitu uji normalitas, uji multikolienaritas, uji heteroskedastisitas, dan uji autokorelasi. Uji normalitas dilakukan dengan menggunakan uji Kolmogorov-Smirnov, residual berdistribusi normal jika nilai signifikansi lebih dari 0,05 . Uji multikolienaritas dilakukan dengan melihat nilai Varience Inflation Factor (VIF). Prasyarat yang harus dipenuhi dalam model regresi yaitu tidak adanya multikolinearitas. Jika nilai $\mathrm{VIF}<5$ atau VIF $<10$ dan mempunyai angka tolerance $>0,1$ 
maka antar variabel independen dalam model tidak terjadi persoalan multikolinearitas. Jika nilai VIF $>5$ dan mempunyai angka Tolerance $<0,1$, maka antar variabel independen terjadi persoalan multikolinearitas.

Uji heteroskedastisitas yang digunakan dalam penelitian ini adalah uji Glejser, jika korelasi antara variabel independen dengan residual di dapat signifikan $>5 \%$ maka tidak terjadi masalah heteroskedastisitas pada model regresi dan jika korelasi antara variabel independen dengan residual di dapat signifikan $<5 \%$ maka terjadi masalah heteroskedastisitas pada model regresi. Uji autokorelasi dilakukan melalui pengujian terhadap nilai uji DurbinWatson (uji DW) dengan ketentuan sebagai berikut : (1) Bila nilai DW terletak di antara batas atas atau upper bound (du) dan (4-du) maka koefisien autokorelasi $=0$, berarti tidak ada autokorelasi. (2) Bila nilai DW lebih rendah dari pada batas bawah atau lower bound (dl) maka koefisien autokorelasi $>0$, berarti ada autokorelasi positif. (3) Bila nilai DW lebih besar dari (4-dl) maka koefisien autokorelasi $<0$, berarti ada autokorelasi negatif. (4) Bila nilai DW terletak antara du dan dl atau DW terletak antara (4-du) dan (4-dl) maka hasilnya tidak dapat disimpulkan. Prasyarat yang harus terpenuhi adalah tidak adanya autokorelasi pada model regresi.

\section{Pengujian Hipotesis}

Pengujian hipotesis dilakukan agar dapat menjawab setiap hipotesis yang dibuat. Proses pengujianhipotesis dalampenelitianinidilakukan melalui beberapa tahapan diantarnya mencari nilai koefisien determinan $\left(\mathrm{R}^{2}\right)$, melakukan uji model (uji F) dan melakukan uji parsial (uji t). Koefisien determinasi merupakan koefisien yang menentukan seberapa besar kemampuan variasi variabel independen dalam menjelaskan variabel dependen. Koefisien determinasi dihitung dengan mengkuadratkan Koefisien Korelasi (R) menjadi Adjusted $R$ Square $\left(\mathrm{R}^{2}\right)$. Jika $\mathrm{R}^{2}=0$, maka tidak ada persentase sumbangan pengaruh yang diberikan variable independen terhadap variabel dependen, sebaliknya jika $R^{2}=1$, maka persentase sumbangan pengaruh yang diberikan variabel independen terhadap variabel dependen adalah sempurna.

Uji F digunakan untuk menguji signifikansi pengaruh variable independen terhadap variable dependen secara simultan dan untuk menguji kelayakan model (Good of Fit.) Uji F dilakukan pada tingkat signifikansi $(\alpha)=0,05$. Bila $\mathrm{F}_{\text {hitung }}<$ $\mathrm{F}_{\text {tabel}}$, variabel independen secara simultan tidak berpengaruh terhadap variabel dependen. Bila $\mathrm{F}_{\text {hitung }}>\mathrm{F}_{\text {tabel }}$, variabel independen secara bersama-sama berpengaruh terhadap variabel dependen. Berdasarkan probabilitas, hipotesis akan diterima jika nilai probabilitasnya $<0,05$ $(\alpha)$. Uji t digunakan untuk menguji signifikansi pengaruh variable independen terhadap variable dependen secara parsial. Oleh karena itu, uji $\mathrm{t}$ ini digunakan untuk menguji hipotesis $\mathrm{H}_{1}$, $\mathrm{H}_{2}, \mathrm{H}_{3}, \mathrm{H}_{4}$ dan $\mathrm{H}_{5}$. Uji $\mathrm{t}$ dilakukan pada tingkat signifikansi $(\alpha)$ sebesar 0,05 . Hipotesis diterima jika tingkat signifikansi $\leq 0,05$ pada tingkat signifikasi $(\alpha)$ sebesar 0,05 . Jika $-t_{\text {tabel }} \leq-t_{\text {hitung }}$ atau $\mathrm{t}_{\text {hitung }} \leq \mathrm{t}_{\text {tabel }}$ maka $\mathrm{H}_{0}$ diterima karena variabel independen secara parsial tidak berpengaruh. Jika terhadap variabel dependen $t_{\text {hitung }}>t_{\text {tabel }}$ atau $-t_{\text {hitung }}<-t_{\text {tabel }}$. Maka $\mathrm{H}_{0}$ diterima karena variabel independen secara parsial berpengaruh terhadap variable dependen.

\section{Analisis Regresi Berganda}

Analisis ini bertujuan mengetahui arah hubungan antara variabel independen dengan variabel dependen apakah menunjukkan arah hubungan postif atau negatif dan untuk memprediksi nilai dari variabel dependen apabila nilai variable independen mengalami kenaikan atau penurunan, teknik analisis regresi berganda dalam penelitian ini dilakukan dengan menggunakan SPSS. Dalam penelitian varibel dependennya adalah tax avodance $(E T R)$ dan untuk varibel independennya terdiri dari profitabilitas (ROA), leverage (LEV), capital intensity (CAPINT), inventory intensity 
(INVINT) dan Likuiditas (CR). Berdasarkan rumusan hipotesis yang dikemukakan diatas maka model persamaan regresinya didituliskan sebagai berikut:

$$
\begin{gathered}
E T R=a+\beta_{t} R O A-\beta_{2} L E V-\beta_{3} C A P I N T+ \\
\beta_{4} I N V I N T+\beta_{5} C R+e
\end{gathered}
$$

\section{Hasil Penelitian dan Pembahasan}

Data statistik deskriptif menunjukkan bahwa nilai standar deviasi untuk tax avoidance, profitabilitas, leverage, capital intensity dan inventory intensity lebih kecil dari nilai mean sedangkan untuk variabel likuiditas nilai standar deviasinya lebih besar dari nilai meannya. Nilai standar deviasi yang lebih kecil dari nilai meannya menunjukkan bahwa sebaran data homogen sehingga sampel dapat mempresentasikan populasi sebaliknya nilai standar deviasi yang lebih besar dari nilai meannya menunjukkan bahwa sebaran data yang cukup tinggi sehingga sampel tidak dapat mempresentasikan populasi.

Hasil uji kolmogorov-Smirnov, diperoleh nilai signifikansi (Asymp.Sig. 2-tailed) sebesar 0,200 . Syarat yang harus dipenuhi agar data berdistribusi normal, nilai signifikansinya diatas 0,05. Dengan demikian maka dapat disimpulkan bahwa data sampel memenuhi standar normalitas. Hasil uji multikolinearitas menunjukkan bahwa semua nilai Tolerance dari masing-masing variabel bebas adalah lebih dari 0,1 sedangkan nilai VIF untuk semua variabel independen tersebut adalah kurang dari 5. Syarat yang harus dipenuhi dalam model regresi agar tidak terjadi multikolinearitas adalah nilai $\mathrm{VIF}<5$ atau $\mathrm{VIF}<10$ dan mempunyai angka tolerance $>0,1$. Oleh karena itu, dapat disimpulkan bahwa antar variabel independen dalam model tidak terjadi multikolinearitas.

Hasil uji heteroskedastisitas menunjukkan bahwa untuk variable leverage, capital intensity dan likuiditas signifikansinya diatas 0.05 sedangkan untuk variabel profitabilitas dan inventory intensity signifikansinya dibawah 0,05. Dikarenakan terdapat variabel yang nilai signifikansinya dibawah 0.05 maka dapat disimpulkan bahwa pada model regresi terdapat masalah heteroskedastisitas. Hasil uji autokolerasi menunjukkan bahwa bahwa nilai Durbin-Watson sebesar 1,867. Sementara dari tabel DW dengan nilai signifikansi 0,05 dan jumlah data $(n)=330$, serta $K=6$ (jumlah variabel) diperoleh nilai du sebesar 1,789 dan nilai dl sebesar 1,850. Karena nilai DW sebesar 1,867 terletak diantara nilai du sebesar 1,789 dan nilai 4-d $(4-1,867=2,133)$ maka dapat disimpulkan tidak terjadi autokorelasi. Hasil pengujian hipotesis terangkum pada table berikut.

Tabel 2. Rangkuman Hasil Uji Hipotesis

\begin{tabular}{lccc}
\hline \multicolumn{1}{c}{ Variabel } & Beta & t-hitung & Sig.t \\
\hline Profitabilitas (ROA) & $-0,039$ & $-2,034$ & 0,043 \\
Leverage (LEV) & $-0,003$ & $-0,271$ & 0,787 \\
Capital Intensity (CAPINT) & 0,063 & 5,584 & 0,000 \\
Inventory Intensity (INVINT) & 0,046 & 3,139 & 0,002 \\
Likuiditas (CR) & 0,000 & $-1,476$ & 0,141 \\
Constant & 0,223 & 30,730 & 0,000 \\
\hline R Square & 0,126 & & \\
Adjusted R Square & 0,113 & & \\
F-hitung & 9,351 & & \\
Sig.F & 0,000 & & \\
\hline
\end{tabular}

Sumber : Data diolah

Berdasarkan tabel 2. diatas maka dapat diketahui diantaranya nilai Adjusted $R$ Square sebesar 0,113 yang berarti bahwa hanya $11,30 \%$ variasi variabel dependen dapat dijelaskan oleh 
variable independennya sedangkan sisanya $88,70 \%$ diduga dipengaruhi atau dijelaskan oleh variabel lain yang tidak dimasukkan dalam model penelitian ini. Nilai $\mathrm{F}$ hitung diketahui sebesar 9,351 dengan signifikansi 0,000 pada tingkat signifikansi 0,05 Nilai F hitung sebesar 9,351 jika dibandingkan dengan $\mathrm{F}$ table pada tingkat signifikasi 0.05 dengan derajat bebas $(\mathrm{df1})=\mathrm{k}-1$ atau 6-1 $=5$ dan df2 $=\mathrm{n}-\mathrm{k}$ atau 330$6=324$, maka dapat diperoleh F table sebesar 2,242. Dikarenakan $\mathrm{F}_{\text {hitung }}>\mathrm{F}_{\text {tabel }}(9,351>2,242)$ maka variabel independen secara simultan berpengaruh terhadap variabel dependen. Hasil pengujian tersebut menunjukan bahwa model regresi telah memenuhi uji Goodness of Fit. Variabel profitabilitas memiliki koefisien beta sebesar -0,039, nilai signifikansi 0,043 pada tingkat signifikansi 0,05 dan nilai t hitung $-2,034$ lebih besar dari nilai $\mathrm{t}$ tabel yaitu $-1,967\left(-\mathrm{t}_{\text {tabel }} \leq\right.$ $-\mathrm{t}_{\text {hitung }}$ atau $\left.-1,967 \leq-2,034\right)$ maka dapat dikatakan profitabilitas berpengaruh negatif signifikan terhadap ETR yang berarti bahwa profitabiltas berpengaruh positif signifikan terhadap tax avoidance. Dengan demikian, hipotesis pertama $\left(\mathrm{H}_{1}\right)$ yang menyatakan bahwa profitabilitas berpengaruh negatif terhadap tax avoidance tidak terbukti.

Variabel leverage memiliki koefiesien beta sebesar $-0,003$, signifikansi sebesar 0,787 pada tingkat signifikansi 0,05 dan nilai t hitung sebesar $-0,271$ lebih kecil dari nilai $t$ tabel yaitu $-1,967$ $\left(-\mathrm{t}_{\text {hitung }}<-\mathrm{t}_{\text {tabel }}\right.$ atau $\left.-0,271<-1,967\right)$ maka dapat dikatakan leverage tidak berpengaruh signifikan terhadap ETR yang berarti bahwa leverage tidak berpengaruh signifikan terhadap tax avoidance. Dengan demikian hipotesis kedua (H2) yang menyatakan bahwa leverage berpengaruh positif terhadap tax avoidance tidak terbukti. Variabel capital intensity memiliki koefisien beta sebesar 0,063 , nilai signifikansi sebesar 0,000 pada tingkat signifikansi 0,05 dan nilai $\mathrm{t}$ hitung sebesar 5,584 lebih besar dari nilai $t$ tabel yaitu $1,967\left(\mathrm{t}_{\text {hitung }}>\mathrm{t}_{\text {tabel }}\right.$ atau $\left.5,584>1,967\right)$ maka dapat dikatakan capital intensity berpengaruh positif signifikan terhadap ETR yang berarti bahwa capital intensity berpengaruh negatif signifikan terhadap tax avoidance. Dengan demikian hipotesis ketiga $\left(\mathrm{H}_{3}\right)$ yang menyatakan bahwa capital intensity berpengaruh positif terhadap tax avoidance tidak terbukti.

Variabel inventory intensity memiliki koefisien beta sebesar 0.046 , nilai signifikansi sebesar 0,002 pada tingkat signifikansi 0,05 dan nilai t hitung sebesar 3,139 lebih besar dari nilai $\mathrm{t}$ tabel yaitu $1,967\left(\mathrm{t}_{\text {hitung }}>\mathrm{t}_{\text {tabel }}\right.$ atau $\left.3,139>1,967\right)$ maka dapat dikatakan bahwa inventory intensity berpengaruh positif dan signifikan terhadap ETR yang berati bahwa inventory intensity berpengaruh negatif signifikan terhadap tax avoidance. Dengan demikian hipotesis keempat $\left(\mathrm{H}_{4}\right)$ yang menyatakan bahwa inventory intensity berpengaruh negatif terhadap tax avoidance terbukti. Variabel likuiditas memiliki koefisien beta sebesar 0,000 , nilai signifikansi sebesar 0,141 pada tingkat signifikansi 0,05 dan nilai t hitung sebesar -1,476 lebih kecil dari t tabel pada angka $t$ tabel yaitu $-1,967\left(-\mathrm{t}_{\text {hitung }}<-\mathrm{t}_{\text {tabel }}\right.$ atau $-1,476<-1,967)$ maka dapat katakana bahwa likuiditas tidak berpengaruh signifikan terhadap ETR yang berarti bahwa likuiditas tidak berpengaruh signifikan terhadap tax avoidance. Dengan demikian hipotesis kelima $\left(\mathrm{H}_{5}\right)$ yang menyatakan bahwa likuiditas berpengaruh negatif terhadap tax avoidance tidak terbukti.

Analisis regresi linier berganda digunakan untuk mengetahui arah hubungan antara variabel independen dengan variabel dependen apakah postif atau negatif dan untuk memprediksi nilai dari variabel dependen apabila nilai variable independen mengalami kenaikan atau penurunan sehingga dapat mengukur besarnya pengaruh variabel independen terhadap variabel dependen. Berdasarkan tabel 2 dapat diketahui nilai constant koefisien beta $(\beta)$ atau koefisien regresi sebesar 0.223 yang dapat diartikan bahwa apabila variable profitabilitas, leverage, capital intensity, inventory intensity likuiditas bernilai 0 (nol) maka nilai ETR akan tetap sebesar 0.223, sehingga dari hasil pengujian statistik dapat diperoleh persamaan regresi sebagai berikut : 


$$
E T R=0,223-0,039 R O A-0,003 L E V+0,063 C A P I N T+0,046 I N V I N T+0,000 C R+e
$$

Lemahnya kemampuan variasi variable independen dalam menjelaskan atau mempengaruhi variabel dependen dapat disebabkan karena kurangnya variasi variable independen yang digunakan dalam model penelitian ini, selain itu kemungkinan lain dapat disebabkan karena model ETR dinilai kurang efektif sebagai proksi tax avoidance hal ini mengacu pada Surat Edaran Direktur Jenderal Pajak Nomor SE-96/PJ/2009 tanggal 05 Oktober 2009 tentang rasio total benchmarking, bahwa salah satu rasio yang digunakan untuk menilai kewajaran terhadap rasio pembayaran pajak perusahaan adalah CTTOR (Corporate Tax to Turn Over Ratio) yang diukur dari perbandingan beban pajak terhadap total penjualan bersih. Meskipun demikian dalam penelitian ini tetap menggunakan proksi ETR karena mengacu pada penelitian sebelumnya.

\section{Pengaruh Profitabilitas terhadap Tax Avoidance}

Profitabilitas merupakan rasio untuk menilai kemampuan perusahaan dalam mencari keuntungan. Rasio ini memberikan ukuran tingkat efektivitas manajemen suatu perusahaan, hal ini ditunjukan oleh laba yang dihasilkan dari penjualan dan pendapatan investasi (Kasmir, 2015 : 196). Menurut Pradipta dan Supriyadi (2015) menyatakan bahwa besar penghasilan yang diperoleh perusahaan maka akan berpengaruh terhadap besarnya pajak penghasilan yang harus dibayarkan. Profitabilitas perusahaan dapat diukur dengan rasio Return On Asset (ROA). Semakin tinggi ROA, semakin tinggi keuntungan perusahaan sehingga semakin baik pengelolaan aktiva perusahaan (Kurniasih dan Sari, 2013). Hal ini berarti bahwa semakin tinggi profitabilitasnya maka semakin baik efektivitas perusahaan dalam mengelola aktivanya untuk menghasilkan laba.

Berdasarkan hasil pengujian hipotesis pertama menunjukan bahwa variable profita- bilitas secara parsial berpengaruh positif signifikan terhadap tax avoidance pada perusahaan manufaktur yang terdaftar di BEI periode 2011-2015. Pengaruh tersebut dapat disebabkan karena perusahaan yang labanya tinggi dalam sampel penelitian ini akan berupaya meminimalisasi beban pajaknya dengan perencanaan pajak yang efektif melalui skema penghindaran pajak tax avoidance. Hasil penelitian ini konsisten dengan hasil penelitian Rinaldi dan Cheisviyanny (2015) dan Darmawan dan Sukartha (2014) menyatakan bahwa profitabilitas berpengaruh positif signifikan terhadap penghindaran pajak (tax avoidance).

\section{Pengaruh Leverage terhadap Tax Avoidance}

Leverage sebagai rasio yang timbul apabila dalam kegiatan operasionalnya perusahaan menggunakan dana pinjaman atau menggunakan dana yang memiliki beban bunga (Siswianti dan Kiswanto, 2016). Semakin besar jumlah dana pinjaman perusahaan maka akan semakin besar beban bunga yang harus dibayarkan oleh perusahaan. Berdasarkan hasil pengujian terhadap hipotesis yang kedua menunjukan bahwa variable leverage secara parsial tidak berpengaruh signifikan terhadap tax avoidance pada perusahaan manufatur yang terdaftar di BEI periode 20112015. Hasil penelitian ini sejalan dengan hasil penelitian yang dilakukan oleh Wijayanti et al. (2016) dan Pradipta dan Supriadi (2015) yang menyatakan bahwa leverage tidak perpengaruh signifikan terhadap tax avoidance.

Perusahaan yang memiliki hutang cukup tinggi akan melakukan berbagai berupaya untuk menjaga laba agar selalu menunjukkan trend positif demi menjaga kepercayaan stakeholder. Namun disatu sisi laba yang trendnya selalu positif dapat menimbulkan beban pajak yang terus meningkat, oleh karena itu perusahaan akan memanfaatkan beban bunga dalam mengatur besarnya laba pada tingkatan tertentu secara merata pada setiap periodenya 
(income smoohting) sehingga besarnya rasio leverage terhadap ETR cenderung sama atau sejajar. Kemugkinan perusahaan manufaktur yang dijadikan sampel dalam penelitian ini melakukan income smoohting sehingga tidak ditemukan adanya pengaruh leverage terhadap tax avoidance karena besarnya rasio leverage terhadap ETR cenderung sama atau sejajar. Selain itu kemungkinan lainnya adalah perusahaan-perusahaan manufaktur yang dijadikan sampel dalam penelitian ini lebih banyak memanfaatkan sumber pendanaan dari hutang kepada pihak afiliasi atau pihak yang memiliki hubungan istimewa sehingga beban bunga yang dibayarkan merupakan deviden yang tidak dapat mengurangi laba kena pajak.

\section{Pengaruh Capital Intensity terhadap Tax Avoidance}

Capital intensity menggambarkan seberapa besar aset perusahaan yang diinvestasikan dalam bentuk aktiva tetap (Mulyani et al., 2014). Aset tetap dapat digunakan oleh perusahaan untuk melakukan penghindaran pajak dengan cara memanfaatkan beban penyusutan yang ditimbulkan dari aset tetap untuk mengurangi laba perusahaan sehingga dapat menurunkan beban pajak menjadi lebih kecil. Berdasarkan hasil pengujian terhadap hipotesis yang ketiga menunjukan bahwa variable capital intensity berpengaruh negatif signifikan terhadap penghindaran pajak (tax avoidance) pada perusahaan manufaktur yang terdaftar di BEI periode 2011-2015. Hasil penelitian ini sejalan dengan hasil penelitin oleh Dharma dan Ardiana (2016), dan Ratmono dan Sagala (2015) yang menyatakan bahwa capital intensity berpengaruh negatif signifikan terhadap terhadap penghindaran pajak (tax avoidance).

Pengaruh negatif variabel capital intensity terhadap tax avoidance menunjukkan bahwa semakin tinggi aset tetap yang dimiliki oleh perusahaan maka akan semakin rendah tingkat penghindaran pajaknya (tax avoidance), kondisi ini kemungkinan dapat disebabkan karena semakin besar jumlah aset tetap perusahaan akan meningkatkan produktivitas perusahaan yang efektif dan efisien dalam menghasilkan keuntungan atau laba yang besar bagi perusahaan, sehingga besarnya beban depresiasi yang timbul dari penyusuan aset tetap tidak mampu mempengaruhi atau menurunkan besarnya laba kena pajak secara signifikan, dengan demikian beban pajak akan tetap tinggi.

\section{Pengaruh Inventory Intensity terhadap Tax Avoidance}

Inventory intensity merupakan subtitusi dari capital intensity yang diukur dengan rasio total persediaan dengan total asset, semakin tinggi nilai persediaan mencerminkan semakin rendahnya nilai harga pokok penjualan sebagai pengurang dalam laba sebelum pajak yang membuat total beban pajak menjadi lebih tinggi hal tersebut karena nilai intensitas persediaan diukur dari total persediaan akhir, dimana untuk harga pokok penjualan sendiri dihitung dari persediaan awal ditambah total pembelian persediaan selama satu tahun dikurangi dengan persediaan akhir (Ratmono dan Sagala, 2015). Menurut Siregar dan Widyawati (2016) menyatakan bahwa perusahaan yang memiliki intensitas persediaan yang tinggi biasanya memiliki rasio Effective Tax Rate (ETR) yang tinggi hal ini dikarenakan perusahaan yang berinvestasi dalam bentuk persediaan tidak dapat melakukan hal yang serupa ketika perusahaan memiliki intensitas modal yang tinggi yakni dalam hal depresiasi yang dapat dijadikan pengurang dalam penghasilan kena pajak.

Berdasarkan hasil pengujian terhadap hipotesis yang keempat menunjukan bahwa variable inventory intensity berpengaruh negatif signifikan terhadap penghindaran pajak (tax avoidance) pada perusahaan manufatur yang terdaftar di BEI periode 2011-2015. Hasil penelitian ini didukung dengan hasil penelitian yang dilakukan oleh Ratmono dan Sagala 
(2015) dan Surbakti (2012) yang menyatakan bahwa inventory intensity berpengaruh negatif signifikan terhadap penghindaran pajak (tax avoidance). Pengaruh negatif variabel inventory intensity terhadap tax avoidance dapat disebabkan karena persediaan merupakan aset lancar yang akan habis dalam waktu yang relatif cepat atau kurang dari satu tahun, sehingga persediaan tidak didepresiasikan sebagaimana aset tetap. Selain itu persediaan merupakan sisa barang dagangan yang belum terjual pada akhir periode, sehingga hal ini akan mempengaruhi harga pokok penjualan. Tingginya nilai persediaan maka akan menurukan nilai harga pokok penjualan, semakin rendah nilai harga pokok penjualan maka pengaruhnya akan semakin kecil dalam mengurangi laba sehingga laba akan tetap tinggi dan beban pajak yang dibayarkan oleh perusahaan juga tinggi.

\section{Pengaruh Likuiditas terhadap Tax Avoidance}

Perusahaan yang likuiditasnya tinggi menggambarkan memilki arus kasnya sangat baik sehingga perusahaan tersebut tidak enggan untuk membayar seluruh kewajibannya termasuk membayar pajak sesuai dengan aturan yang berlaku. Sebaliknya perusahaan yang likuiditasnya rendah akan tidak taat terhadap pajak guna mempertahankan arus kas perusahaan daripada harus membayar pajak (Suyanto dan Supramono, 2012). Kemampuan perusahaan untuk melaksanakan kewajiban jangka pendeknya dapat dilihat dari rasio likuiditas (Adisamartha dan Noviari, 2015). Berdasarkan hasil penelitian yang telah dilakukan dengan menggunakan analisa regresi berganda dan dengan hasil hipotesis kelima yang menunjukkan bahwa variable likuiditas tidak berpengaruh signifikan terhadap penghindaran pajak (tax avoidance) pada perusahaan manufaktur yang terdaftar di BEI periode 2011-2015. Hasil penelitian didukung oleh hasil penelitian yang dilakukan oleh Tiaras dan Wijaya (2015) dan Suyanto dan Supramono
(2012) yang menyatakan bahwa likuiditas tidak berpengaruh signifikan terhadap penghindaran pajak (tax avoidance).

Tidak adanya pengaruh variabel likuiditas terhadap tax avoidance dapat disebabkan karena current ratio atau likuiditas lebih mengambarkan tingginya aset lancar perusahaan dalam bentuk dana tunai, semakin besar jumlah dana tunai yang dimilki oleh perusahaan maka dapat memunculkan persepsi negatif terhadap rendahnya efektifitas manajemen dalam mengelola keuangan karena sumber daya keuangan perusahaan tidak produktif. Namun jika rasio likuiditas perusahaan rendah juga akan menunjukan tingginya risiko perusahaan karena memiliki kemampuan yang rendah dalam menjamin pelunasan seluruh hutang jangka pendeknya. Sehingga hal ini dapat menurunkan tingkat kepercayaan pihak ketiga. Oleh karena itu ada kemugkinan perusahaanperusahaan manufaktur yang dijadikan sampel dalam penelitian ini akan selalu berusaha untuk menjaga likuiditas perusahaan pada tingkatan tertentu sehingga tidak dapat ditemukan adanya pengaruh likuiditas terhadap tax avoidance.

\section{Simpulan, Keterbatasan dan Implikasi Hasil Penelitian}

Berdasarkan hasil penelitian mengenai pengaruh profitabilitas, leverage, capital intensity, inventory intensity, dan likuiditas terhadap tax avoidance pada perusahaanperusahan manufaktur yang terdaftar di BEI tahun 2011-2015, maka hasil penelitian secara empiris dapat dapat disimpulkan bahwa variabel Profitabilitas berpengaruh positif signifikan terhadap tax avoidance, variabel leverage dan likuiditas tidak berpengaruh signifikan terhadap tax avoidance sedangkan variable capital intensity dan inventory intensity berpengaruh negatif signifikan terhadap tax avoidance.

Keterbatasan dalam penelitian ini diantaranya adalah objek penelitian yang terbatas hanya pada perusahaan-perusahaan 
manufaktur yang terdaftar di BEI pada periode 2011- 2015 sehinga menyebakan hasil yang kurang optimal, kurangnya variable independen yang digunakan dalam model penelitian sehingga variasi variable dependen kurang mampu menjelaskan variable dependennya, dan terdapat masalah heteroskedastisitas pada dua variabel independen yaitu profitabilitas dan inventory intensity sehingga hasil penelitan ini menjadi lemah. Berdasarkan hasil penelitian ini, maka peneliti dalam hal ini dapat menyampaikan beberapa saran diantaranya agar penelitian selanjutnya dapat memperluas objek penelitian atau periode penelitian bukan hanya pada perusahaan-perusahaan manufaktur saja, menambah variable independennya dan menggunakan proksi lain selain ETR dalam mengukur tax avoidance seperti CTTOR (Corporate Tax to Turn Over Ratio) hal ini mengacu pada ketentuan peraturan perpajakan yaitu Surat Edaran Direktur Jenderal Nomor SE-96/PJ/2009 tentang rasio benchmarking, sehingga hasil penelitian diharapkan dapat lebih mencerminkan kondisi yang sesungguhnya.

\section{Daftar Referensi}

Adisamartha, Noviari. 2015. Pengaruh Likuiditas, Leverage, Intensitas Persediaan Dan Intensitas Aset Tetap Pada Tingkat Agresivitas Wajib Pajak Badan. E-Jurnal Akuntansi Universitas Udayana 13 (3): 973-1000.

Bursa Efek Indonesia. http://www.idx.co.id/ id-id/ beranda/ perusahaantercatat/ laporankeuangantahunan.aspx, diunduh, 10 Oktober 2016

Bradley, C.F. 1994. Am Empirical Investigation of Factors Affecting Corporate Tax Compliance Behavior. Ph.D,Thesis. Uniersity of Alabama, Culverhouse School of Accountancy.

Cahyono, Andini, Raharjo. 2016. Komite Audit, Kepemilikan Institusional, Dewan Komisaris, Ukuran Perusahaan, leverage, dan Profitabilitas Terhadap Tindakan
Penghindaran Pajak Pada Perusahaan Perbankan yang Listing Di BEI Periode Tahun 2011-2013. Journal of Accounting 2 (2).

Darmawan, Sukartha. 2014. Pengaruh Penerapan Corporate Governace, Leverage, Return On Assets, Dan Ukuran Perusahaan Pada Penghindaran Pajak. E-Jurnal Akuntansi Universitas Udayana.9.1: 143-161.

Dharma, Ardiana. 2016. Pengaruh Leverage, Intensitas Aset Tetap, Ukuran Perusahaan, Dan Koneksi Politik Terhadap Tax Avoidance. E-Jurnal Akuntansi Universitas Udayana 15 : 584-613.

Financial Bisnis, penerimaan pajak pertambangan dan manufaktur pemicu penurunan $\mathrm{PPh}, \quad \mathrm{http} / / /$ finansial.bisnis. com/read/20121221/9/111083, diunduh, 30 Januari 2017

Imam Santoso, Ning Rahayu. Corporate Tax Management. Jakarta, Observation \& Research of Taxation (ortax), 2013.

Jesscica, Toly. 2014. Pengaruh Pengungkapan Corporate Responsibility Terhadap Agresivitas Pajak. Tax \& Accounting Review 4 (1).

Kasmir. Analisis Laporan Keuangan. Jakarta, Rajawali Pers, 2015.

Kementrian Keuangan. Laporan Keuangan, http://www.kemenkeu.go.id/ publikasi/ laporan-keuangan, diunduh, 15 September 2016

Kurniasih, Sari. 2013. Pengaruh ROA, Leverage, Corporate Governance, Ukuran Perusahaan, Dan Kompensasi Rugi Fiskal Pada Tax Avoidance. Buletin Studi Ekonomi 18 (1).

Lanis, Richardson. 2011. Corporate Social Responsibility and Tax Aggressiveness An Empirical Analysis. Elsevier

Mayangsari. 2015. Pengaruh Kepemilikan Eksekutif, Kepemilikan Saham Eksekutif, Preferensi Resiko Eksekutif Dan Leverage Terhadap Penghindaran Pajak. Jom FEKON 2 (2), 2015. 
Mulyani, S., Darminto., dan Endang, M.W. 2014. Pengaruh Karakteristik Perusahaan, Koneksi Politik dan Reformasi Perpajakan Terhadap Penghindaran Pajak (Studi pada perusahaan manufaktur yeng terdaftar di BEI tahun 2008-2012). Jurnal Mahasiswa Perpajakan Universitas Brawijaya, Vol. 1, No. 2, 2014, hal 1-9.

Pradipta, Supriadi. 2015. Pengaruh CSR, Profitabilitas, Leverage, dan Komisaris Independen Terhadap Praktik Penghindaran Pajak. Simposium Nasional Akuntansi 18 Universitas Sumatera Utara Medan.

Prakosa. 2014. Pengaruh Profitabilitas, Kepemilikan Keluarga Dan Corporate Governace Terhadap Penghindaran Pajak Di Indonesia. Seminar Nasional Akuntansi 17 Mataram Lombok Universitas Mataram. Ratmono, Sagala. 2015. Pengungkapan CSR Sebagai Sarana Legitimasi :Dampaknya Terhadap Tingkat Agresivitas Pajak. Jurnal Nominal IV (2).

Rinaldi, Cheisviyanny. 2015. Pengaruh Profitabilitas, Ukuran Perusahaan Dan Kompensasi Rugi Fiskal Terhadap Tax Avoidance Studi Empiris Pada Perusahaan Manufaktur Yang Terdaftar Di BEI Tahun 2010-2013. Seminar Nasional Ekonomi Manajemen Dan Akuntansi Fakultas Ekonomi Unuversitas Negeri Padang. ISBN : 978-602-17129-5-5.

Siahaan, F.O.P. 2005.Faktor-faktor yang Memengaruhi Perilaku Kepatuhan Tax Profesional Dalam Pelaporan Pajak Badan pada Perusahaan Indsutri Manufaktur di Surabaya.Disertasi.Program Pasca Sarjana Universitas Airlangga.

Siregar, Widyawati. 2016. Pengaruh Karakteristik Perusahaan Terhadap Penghindaran Pajak Pada Perusahaan Manufaktur Di BEI. Jurnal Ilmu Dan Riset Akuntansi 5 (2). ISSN : 2460-0585.

Siswianti, Kiswanto. 2016. Analisis Determinan Tax Aggressiveness Pada Perusahaan Multinasional. Accounting Analysis Journal 5 (1).

Surbakti, T. A. V. 2012. Pengaruh Karakteristik Perusahaan Dan Reformasi Perpajakan Terhadap Penghindaran Pajak Di Perusahaan Industri Manufaktur Yang Terdaftar DI Bursa Efek Indonesia Tahun 2008-2010. Skripsi. Universitas Indonesia. Depok.

Suyanto, Supramono. 2012. Likuiditas, Leverage, Komisaris Independen Dan Manajemen Laba Terhadap Agresivitas Pajak Perusahaan. Jurnal Keuangan dan Perbankan 16 (2) : 167-177.

Tiaras, Wijaya. 2015. Pengaruh Likuiditas, Leverage, Manajemen Laba, Komisaris Independen Dan Ukuran Perusahaan Terhadap Agresivitas Pajak. Jurnal Akuntansi XIX (03) : 380-397.

Wijayanti,Wijayanti, Samrotun. 2016. Pengaruh Karakteristik Perusahaan, GCG Dan CSR Terhadap Penghindaran Pajak. Seminar Nasional IENACO. ISSN : 2337-4349.

Wild, Subramayam, Halsey. Financial Statement Analysis. Jakarta, Salemba Empat, 2005. 